\title{
Pengembangan Assesment of Inovation Learning Berbasis Revolusi Industri 4.0. untuk Guru Sekolah Dasar
}

\author{
*Pinkan Amita Tri Prasasti ${ }^{1}$, Candra Dewi ${ }^{2}$ \\ ${ }^{12}$ Prodi Pendidikan Guru Sekolah Dasar Universitas PGRI Madiun, Medium, Indonesia
}

\author{
A R T I C L E I N F O \\ Article history: \\ 25 December 2019 \\ Received in revised form \\ 01 January 2020 \\ Accepted 25 January 2020 \\ Available online 28 \\ February 2020 \\ Kata Kunci: \\ Assesment, Revolusi Industri \\ 4.0, Sekolah Dasar \\ Keywords: \\ Assesment, Industrial \\ Revolution 4.0, Elementary \\ School
}

\begin{abstract}
A B S T R A K
Salah satu bagian penting dari pelaksanaan pembelajaran yang tidak dapat diabaikan adalah pelaksanaan penilaian. Penilaian tidak hanya dilakukan sesaat, akan tetapi harus dilakukan secara berkala dan berkesinambungan selama proses belajar mengajar. Dalam penilaian, guru harus mampu mencapai tujuan pembelajaran yang diharapkan untuk mengetahui kemauan belajar peserta didik dan potensi belajar peserta didik sehingga hal itu tentunya harus didukung oleh model penilaian dan metode pembelajaran yang baik dan tepat. Penelitian ini bertujuan mengembangakan produk berupa Assessment Of Inovation Learning Berbasis Revolusi Industri 4.0 untuk Guru Sekolah Dasar. Pengembangan mengacu pada model 4D Thiagarajan Prosedur pengembangan menggunakan langkah-langkah pengembangan yaitu tahap pengumpulan informas, tahap perencanaan, tahap pengembangan dan tahap validasi dan uji coba. Pada tahap uji coba skla terbatas menggunakan intrumen berupa lembar validasi yang
\end{abstract} melibatkan 3 orang validator ahli dari segi materi, bahasa dan penyajian dan juga produk telah diujicobakan pada 40 pengguna yang terdiri dari 10 responden guru. Assessment Of Inovation Learning Berbasis Revolusi Industri 4.0. pada Guru Sekolah Dasar telah memenuhi kriteria 86.67\% dinyatakan dalam kriteria sangat layak dari validator ahli bahasa, $88.89 \%$ dinyatakan dalam kriteria sangat layak dari validator ahli materi, $87.06 \%$ dinyatakan dalam kriteria sangat layak dari validator ahli penyajian, $84.29 \%$ dinyatakan dalam kriteria sangat layak.

\begin{abstract}
A B S T R A C T
One important part in implementing learning that cannot be ignored is the implementation of assessment. It is not only done for a moment but must be done regularly and continuously throughout the teaching and learning process. In the assessment, the teacher must be able to achieve the learning objectives that are expected to know the student's willingness to learn and also know the students' learning potential, so that it certainly must be supported by a good and appropriate assessment model and learning method. This research aimed to develop a product in the form of assessment of innovation learning based on the industrial revolution 4.0 for elementary school teachers. Assessment is a process to obtain information in any form that can be used for the basis of decision making about students and teachers, both regarding curriculum, learning programs, and school climate and school policy. Development refers to the 4D Thiagarajan model. The development procedure used development steps, namely the information gathering step, the planning step, the development step, and the validation and trial step. Elementary school teachers had fulfilled the criteria and $86.67 \%$ stated in very feasible criteria of the linguist validator, $88.89 \%$ stated in the very feasible criteria of the material expert validator, $87.06 \%$ stated in the very feasible criteria of the design expert validator, $84.29 \%$ stated in the very feasible criteria from the teacher validator.
\end{abstract}




\section{Pendahuluan}

Perkembangan teknologi informasi di Indonesia memiliki kemajuan yang sangat pesat. Perkembanganini tengah memasuki era revolusi 4.0. evolusi industri dunia ke-empat dimana teknologi telah menjadi basis dalam kehidupan manusia. Segala hal tanpa batas dan tidak terbatas akibat perkembangan internet dan teknologi digital. Di era revolusi industri 4.0. ini telah mempengaruhi banyak aspek kehidupan baik di bidang ekonomi, politik, kebudayaan, seni, bahkan sampai ke dunia pendidikan. Menyiapkan lulusan yang berkualitas dan mampu bersaing secara global serta menguasai perkembangan teknologi merupakan hal yang penting untuk semua orang dan penting bagi masa depan suatu negara. Dengan demikian, dukungan dan peran pendidikan tinggi tersebut diharapkan mampu meningkatkan daya saing bangsa Indonesia di tengah persaingan global dan pesatnya perkembangan teknologi informasi. Salah satu cara mencerdaskan kehidupan bangsa adalah dengan melalui pendidikan. Pendidikan sangatlah penting dalam meningkatkan sumber daya manusia yang berkualitas. Dalam meningkatkan sumber daya manusia yang berkualitas maka dibutuhkan pula pendidikan yang berkualitas dan tenaga pendidik yang profesional serta berkualitas.

Adapun hubungan dunia pendidikan dengan revolusi industri 4.0. adalah dunia pendidikan dituntut harus mengikuti perkembangan teknologi yang sedang berkembang pesat serta memanfaatkan teknologi informasi dan komunikasi sebagai fasilitas yang lebih dan serba canggih untuk memperlancar proses pembelajaran pada peserta didik.Bagi seorang pendidik, pesatnya perkembangan teknologi merupakan peluang yang dapat dimanfaatkan untuk mengembangkan suatu inovasi dalam pembelajaran. Selain itu, diharapkan dengan pemanfaatan teknologi informasi dan komunikasi tersebut mampu menjadikan pola pikir pembelajaran bergeser dari berpusat pada guru (teacher centered) menjadi berpusat pada peserta didik (student centered).

Seharusnya pada saat ini, guru pada era revolusi industri 4.0. benar-benar merupakan seorang guru yang profesional agar mampu menghadapi tantangan. Untuk itu, kompetensi kepribadian, kompetensi profesional, dan kompetensi sosial, serta kompetensi pedagogik seorang guru perlu dikembangkan sehingga mampu mendidik siswa yang mempunyai kemampuan memprediksi dan menanggulangi. Di sisi lain, tugas-tugas guru yang bersifat profesional harus ditunjang oleh sistem penghargaan yang sesuai, sehingga guru mampu memfokuskan diri pada peningkatan kualitas layanan yang diberikan. Seseorang yang berprofesi sebagai guru harus mampu mengatur strategi belajar, membantu melayani, memenuhi, menciptakan dan memfasilitasi kegiatan belajar dengan menerapkan prinsip peserta didik belajar aktif, yaitu dengan pembelajaran yang melibatkan seluruh aspek perkembangan peserta didik baik secara fisik, mental (pemikiran dan perasaan) dan sosial, serta sesuai dengan tingkat perkembangan anak (Kosasih $2009: 2)$.

Program dan proses pembelajaran (proses belajar mengajar) harus diarahkan pada kegiatan yang dapat mengoptimalkan kegiatan belajar mengajar peserta didik. Selanjutnya untuk mengetahui apakah guru mampu mencapai tujuan-tujuan pembelajaran yang diharapkan untuk mengetahui kemauan belajar peserta didik, kemampuan serta potensi belajar peserta didik, tentunya harus didukung oleh model penilaian dan metode pembelajaran yang baik dan tepat. Penilaian tidak hanya dilakukan sesaat, akan tetapi harus dilakukan secara berkala dan berkesinambungan selama proses belajar mengajar. Pelaksanaan penilaian bukan hanya menilai sesuatu secara parsial, melainkan harus menilai sesuatu secara menyeluruh yang meliputi proses dan hasil belajar siswa. Salah satu bagian penting dari pelaksanaan pembelajaran yang tidak dapat diabaikan adalah pelaksanaan penilaian. Pelaksanaan penilaian dikenal dengan istilah Assessment.

Penilaian atau asssessment adalah proses untuk mendapatkan informasi dalam bentuk apapun yang dapat digunakan untuk dasar pengambilan keputusan tentang siswa maupun guru, baik yang menyangkut kurikulum, program pembelajaran, iklim sekolah maupun kebijakan-kebijakan sekolah. Penilaian yang sering dilakukan oleh guru-guru di Indonesia adalah penilaian sumatif atau Assessment of Learning (AoL).Assessment merupakan suatu istilah umum yang didefinisikan sebagai sebuah proses yang ditempuh untuk mendapatkan informasi yang digunakan dalam rangka membuat keputusan-keputusan mengenai para siswa, kurikulum, program-program, dan kebijakan pendidikan, metode atau instrumen pendidikan lainnya oleh suatu badan, lembaga, organisasi atau institusi resmi yang menyelenggarakan suatu aktivitas tertentu (Uno \& Koni, $2012: 1$ ).

Berdasarkan pendapat ahli tersebut assessment (penilaian) merupakan suatu proses atau upaya yang digunakan untuk mendapatkan suatu informasi maupun data yang berkaitan langsung dengan keputusan-keputusan mengenai peserta didik, proses belajar mengajar pada peserta didik, hasil belajar peserta didik serta format penilain kemajuan belajar peserta didik. Berdasarkan hasil observasi penilaian dilakukan secara manual dengan mengembangkan secara individu yang dilakukan oleh Guru dan 
sebanyak 68\% guru pada kelas observasi awal menggunakan dominansi penilaian pada ranah kognitif dengan menfaatkan tes tertulis. Menurut S.Bola et.al, (2017) dalam penelitiannya diperlukan suatu pedoman menyeluruh dalam proses penilaian agar mempermudah bagi guru saat melakukan penilaian. Proses penilaian saat ini sangat komplek dan tidak memungkinkan hanya dilakukan oleh satu orang guru dalam satu kelas. Untuk itu diperlukan bantuan teknologi dalam membantu guru selama penilaian. Produk Assement berbasis revolusi industri dikembangkan dengan menggunakan program Mc. Acces dimana di dalam program tersebut telah memuat komponen-komponen penilaian yang dapat membantu guru dalam mendokumentasikan penilaian siswa. Produk ini dikembangkan agar membantu guru untuk lebih praktis, efektif dan efisien dalam mengelolan penialaian sisiwa baik secara kognitif, afektif maupun psikomotor bahkan untuk merancang dan menyimpan portofolio/tugas berbasis proyek yang dilakukan siswa. program ini dapat diakses dimanapun dan dalam kondisi apapun meskipun tidak terhubung dengan internet, sehingga guru-guru dipelosok tidak perlu khawatir dalam menggunakan program ini. Bagian penting dari assessment pembelajaran ini adalah bagaimana cara melakukan penilaian, bagaimana prosedur penilaian, pengolahan data, penetapan skor (nilai) hingga pelaporannya. Setiap adanya perkembangan dan kemajuan pada sistem pendidikan maka akan di adakannya perubahan juga pada sistem pembelajaran maupun penilaian. Hal ini dianggap penting untuk diteliti dikarenakan suatu penilaian tersebut memang berhak diteliti agar peneliti mampu mengembangkan penilaian yang belum berkembang mengikuti kemajuan teknologi yang ada.

\section{Metode}

Jenis penelitian ini adalah penelitian pengembangan (RnD) denga menerapkan model Thiagarajan (dalam Mulyatiningsih, 2013) terdapat empat langkah penelitian dan pengembangan yang disingkat dengan 4-D , yaitu "define, design, develop and disseminate". Produk yang dihasilkan berupa Assessment of Inovation Learning Berbasis Revolusi Industri 4.0 pada guru sekolah dasar. Penelitian pengembangan tidak hanya menghasilkan produk, tetapi produk yang dihasilkan diuji kelayakannya agar assessment of inovation learning berbasis revolusi industri 4.0.pada guru sekolah dasar dapat digunakan sesuai dengan fungsi dan tujuannya. Proses pengembangan meliputi pada tahap define proses analisi kebutuhaan dan telaah kajian pustaka serta materi, tahap design memuat layout produk yang dikembangkan berdasarkan kajian dan anlisis kebutuhan, develop yaitu mnegmbangkan produk dengan menguji kelayakannya melalui uji validator dan disseminate menyebarluaskan produk melalui kegiatan temu imiah dengan Guru di sekolah mitra.

Instrumen yang digunakan dalam penelitian ini menggunalkan lembar validasi yang berfungsi sebagai kontrol kelayakan produk. Produk ini divalidasi oleh 3 validator yang terdiri dari vaditaor Materi, tata bahasa dan Penyajian produk. Selain validator ahli produk ini juga diuji cobakan pada Pengguna yaitu guru dengan jumlah 30 Responden. Selanjutnya data dihitung dengan menggunakan Rumus

$$
\begin{aligned}
& \mathrm{P}=\frac{\sum x_{i}}{\sum x} \times 100 \% \\
& \mathrm{P}=\frac{\sum p}{n}
\end{aligned}
$$

Keterangan :

$\mathrm{P} \quad=$ Persentase penilaian

$\sum \mathrm{x}_{\mathrm{i}} \quad=$ Jumlah jawaban dari validator

$\sum \mathrm{x} \quad=$ Jumlah jawaban tertinggi

Hasil perhitungan persentase digunakan ketetapan tertera pada Tabel 1

Tabel 1. Pengambilan Keputusan Revisi Pengembangan

\begin{tabular}{ccc}
\hline Tingkat Pencapaian & Kualifikasi & Keterangan \\
\hline $90 \%-100 \%$ & Sangat baik & Tidak perlu direvisi \\
$75 \%-89 \%$ & Baik & Tidak perlu direvisi \\
$65 \%-74 \%$ & Cukup & Direvisi \\
$55 \%-64 \%$ & Kurang baik & Direvisi \\
$0 \%-54 \%$ & Kurang cukup & Direvisi \\
\hline
\end{tabular}




\section{Hasil dan pembahasan}

Penelitian dan pengembangan ini menghasilkan suatu produk pengembangan Assessment of Inovation Learning Berbasis Revolusi Industri 4.0. pada Guru Sekolah Dasar. Pengembangan penelitian ini akan menggunakan model 4-D. Thiagarajan (dalam Mulyatiningsih, 2013) berpendapat bahwa terdapat empat langkah penelitian dan pengembangan yang disingkat dengan 4-D , yaitu "define (pendefinisian), design (perancangan), develop (pengembangan) and disseminate(penyebaran)". Data hasil dari tahapan prosedur penelitian pengembangan yang telah dilakukan akan dijelaskan sebagai berikut.

Tahap Define (pendefinisian) Tahap pendefinisian ini mencakup beberapa aspek penelitian diantaranya: (a) Analisis Ujung Depan (front and analysis) Berdasarkan Kegiatan wawancara yang dilakukan oleh peneliti ditemukan beberapa permasalahan dalam penilaian, (i) Kepala Sekolah sudah memiliki penilaian terkait kinerja guru namun belum memiliki penilaian yang terkait dengan inovasi pembelajaran dan berbasis revolusi industri 4.0. (ii) Kurangnya pemahaman guru terhadap penilaian yang berbasis revolusi industri 4.0. Oleh karena itu, dengan adanya penelitian ini diharapkan Kepala Sekolah dapat menilai kinerja dan inovasi guru dengan buku assessment of inovation learning berbasis revolusi industri 4.0. (b) Analisis Guru (Learner analysis)Analisis yang dilakukan untuk mengetahui pemahaman guru agar sesuai dengan rancangan Assessment Of Inovation Learning Berbasis Revolusi Industri 4.0. pada Guru Sekolah Dasaryang akan dikembangkan. Analisis guru dan ditambah informasi dari Kepala Sekolah,diperoleh gambaran tentang kendala yang dihadapi guru dalampenggunaan assessment ofinovation learning berbasis revolusi industri 4.0.pada guru sekolah dasar pada proses pembelajaran, sehinggaperluadanyapengembangan Assessment Of Inovation Learning Berbasis Revolusi Industri 4.0. pada Guru Sekolah Dasar yang akanmembantuKepala Sekolah untuk lebih mudah memahami materi revolusi industri 4.0 yang akan dinilai. (c) Analisis Materi(concept analysis) Konsep materi penelitian pada penelitian adalah unsur-unsur pembelajaran yang akan dikaitkan dengan perkembangan teknologi tentang Revolusi Industri 4.0. Dengan adanya konsep materi tersebut dapat mejadi acuan peneliti membuat indikator penilaian berbasis revolusi industri 4.0.

Tahap Design (perancangan)Berdasarkan hasil pengumpulan data yang telah diperoleh maka tahapan selanjutnya adalah perencanaan. Tahap perencanan kegiatan yang dilakukan adalah sebagai berikut. (a) Assessment of inovation learning berbasis revolusi industri 4.0. pada guru sekolah dasar yang dihasilkan design awal (Draft I) diserahkan kepada validator untuk divalidasi (b) Validator memiliki wewenang memberikan penilaian dan saran untuk assessment of inovation learning berbasis revolusi industri 4.0. pada guru sekolah dasaryang telah dibuat peneliti. Validator dalam penelitian adalah satu dosen Bahasa Indonesia yaitu ahli Bahasa Apri Kartikasari H S, S.Pd., M.Pd, ahli desain yang juga seorang dosen Informatika Universitas PGRI Madiun Dimas Setiawan dan pengguna yaotu praktisi guru yang tersebar di 7 skolah dasar dengan jumlah responden 30 Guru. Indikator validasi dapat dilihat dari komponen assessment of inovation learning berbasis revolusi industri 4.0. pada guru sekolah dasar, keakuratan, kelengkapan sajian, kesesuaian bahasa dan kaidah instrumen yang baik dan benar. Tahap Pengembangan produk awal merupakan tahap yang selanjutnya dilakukan setelah perencanaan dan pengumpulan data. Data yang diperoleh pada tahapan sebelumnya menjadi acuan produk yang akan dikembangkan dengan terlebih dahulu membuat desain assessment of inovation learning. Produk yang dikembangkan berupa assessment of inovation learning. assessment of inovation learning yang dikembangkan terdiri dari tiga bagian utama sebagai penyusun buku penilaian inovasi pembelajaran berbasis Revolusi Industri 4.0. yaitu bagian awal, bagian inti dan bagian penutup.

Tahap Development (pengembangan) Tahap yang dilkukan selanjutnya setelah pengembangan produk adalah melanjutakan pada tahap uji coba terbatas.Uji coba terbatas dilakukan untuk memperoleh evaluasi kualitatif awal dari draft produk yang telah dibuat. Uji coba permulaan dilakukan dengan uji validasi ahli yang terdiri dari ahli validasi ahli bahasa, ahli desain, ahli materi, dan praktisi guru. Validasi Produk awal yang telah selesai kemudian divalidasi menggunakan angket validasi ahli bahasa. Hasil tabulasi uji ahli bahasa secara lengkap disajikan dalam tabel 2 .

Tabel 2. Tabulasi Uji Ahli Bahasa

\begin{tabular}{lcccc}
\hline Aspek & $\begin{array}{c}\text { Jumlah Setiap } \\
\text { Aspek }\end{array}$ & $\begin{array}{c}\text { Skor } \\
\text { Maksimal }\end{array}$ & Presentase & Kriteria \\
\hline Lugas & 12 & 15 & $80,00 \%$ & Layak \\
Komunikatif & 4 & 5 & $80,00 \%$ & Layak \\
\hline
\end{tabular}




\begin{tabular}{|c|c|c|c|c|}
\hline Dialogis dan interaktif & 4 & 5 & $80,00 \%$ & Layak \\
\hline $\begin{array}{l}\text { Kesesuaian perkembangan peserta } \\
\text { didik }\end{array}$ & 8 & 10 & $80,00 \%$ & Layak \\
\hline Kesesuaian dengan kaidah bahasa & 6 & 10 & $60,00 \%$ & Layak \\
\hline Jumlah Total & \multicolumn{4}{|c|}{34} \\
\hline Skor Maksimal & \multicolumn{4}{|c|}{45} \\
\hline Presentae & \multicolumn{4}{|c|}{$75,55 \%$} \\
\hline Kriteria & \multicolumn{4}{|c|}{ Layak } \\
\hline
\end{tabular}

Berdasarkan tabel 2 di atas menunjukkan hasil tabulasi uji ahli bahasa diperoleh jumlah 34 dengan skor maksimal 45 dengan $75,55 \%$ dinyatakan dalam kriteria layak.

Tabel 3. Tabulasi Uji Ahli Materi

\begin{tabular}{lcccc}
\hline \multicolumn{1}{c}{ Aspek } & $\begin{array}{c}\text { Jumlah Setiap } \\
\text { Aspek }\end{array}$ & $\begin{array}{c}\text { Skor } \\
\text { Maksimal }\end{array}$ & Presentase & Kriteria \\
\hline Isi & 4 & 5 & $80.00 \%$ & Sangat Layak \\
Konstruksi & 55 & 65 & $78.33 \%$ & Layak \\
Tugas yang harus dilakukan & 6 & 10 & $60.00 \%$ & Layak \\
Masalah yang ditampilkan & 8 & 10 & $80.00 \%$ & Sangat Layak \\
Aspek yang dikembangkan & 4 & 5 & $80.00 \%$ & Sangat Layak \\
Jumlah Total & \multicolumn{5}{|c}{$\mathbf{7 7}$} \\
Skor Maksimal & \multicolumn{5}{c}{$\mathbf{8 3 , 3 4 \%}$} \\
Presentae & \multicolumn{5}{c}{ Layak } \\
Kriteria
\end{tabular}

Berdasarkan tabel tersebut menunjukkan hasil tabulasi uji ahli materi diperoleh jumlah 69 dengan skor maksimal 95 dengan $72.63 \%$ dinyatakan dalam kriteria layak.

Tabel 4. Tabulasi Uji Ahli Penyajian

\begin{tabular}{lccll}
\hline \multicolumn{1}{c}{ Aspek } & $\begin{array}{c}\text { Jumlah Setiap } \\
\text { Aspek }\end{array}$ & $\begin{array}{c}\text { Skor } \\
\text { Maksimal }\end{array}$ & Presentase & Kriteria \\
\hline Ukuran buku pedoman penilaian & 1 & 5 & $80.00 \%$ & Sangat Layak \\
guru & 6 & 30 & $76.67 \%$ & Sangat Layak \\
Desain Sampul (Cover) & 10 & 50 & $82.00 \%$ & Sangat Layak \\
Desain Isi & & & $\mathbf{8 5}$ & \\
\hline Skor Maksimal & & $\mathbf{7 0 . 4 \%}$ & \\
\hline Presentae & & Layak & \\
\hline Kriteria & &
\end{tabular}

Berdasarkan tabel 4 menunjukkan hasil tabulasi uji ahli desain diperoleh jumlah 68 dengan skor maksimal 85dengan $70.04 \%$ dinyatakan dalam kriteria layak.

Tabel 05. Tabulasi Uji Guru

\begin{tabular}{lcccc}
\hline \multicolumn{1}{c}{ Aspek } & $\begin{array}{c}\text { Jumlah Setiap } \\
\text { Aspek }\end{array}$ & $\begin{array}{c}\text { Skor } \\
\text { Maksimal }\end{array}$ & Presentase & Kriteria \\
\hline Judul & 3 & 5 & $80.00 \%$ & Sangat Layak \\
Kompetensi & 8 & 10 & $80.00 \%$ & Sangat Layak \\
Kolom Identitas & 7 & 10 & $80.00 \%$ & Sangat Layak \\
Informasi Singkat penilaian & 4 & 5 & $80.00 \%$ & Sangat Layak
\end{tabular}

JISD P-ISSN: 2579-3276 E-ISSN : 2549-6174 


\begin{tabular}{lcccc} 
Langkah kerja & 4 & 5 & $80.00 \%$ & Sangat Layak \\
Tugas yang harus dilakukan & 6 & 15 & $93.33 \%$ & Sangat Layak \\
Laporan yang harus & 4 & 5 & $80.00 \%$ & Sangat Layak \\
dikerjakan & 8 & 10 & $90.00 \%$ & Sangat Layak \\
Masalah yang ditampilkan & 4 & 5 & $80.00 \%$ & Sangat Layak \\
Aspek yang dikembangkan & & $\mathbf{4 8}$ & \\
\hline Jumlah Total & $\mathbf{7 0}$ & \\
\hline Skor Maksimal & & $\mathbf{6 8 . 5 7 \%}$ \\
\hline Presentae & Layak \\
\hline Kriteria & &
\end{tabular}

Berdasarkan tabel tersebut menunjukkan hasil tabulasi uji guru diperoleh jumlah 48 dengan skor maksimal 70 dengan 68.57 \% dinyatakan dalam kriteria layak. Berdasarkan saran sesuai validator ahli maupun praktisi telah dilakukan beberapa perbaikan di dalam buku pengembangan assessment of inovation learning berbasis revolusi industri 4.0.

Analisis kelayakan assessment Of Inovation Learning Berbasis Revolusi Industri 4.0.diperoleh dari hasil pengisian angket sebagai respon guru setelah menggunakan assessment of Inovation Learning Berbasis Revolusi Industri 4.0. Berikut disajikan hasil pengisian angket pada uji coba terbatas. Berdasarkan hasil perhitungan tabel pengisian angket uji coba terbatas diperoleh jumlah skor total 1072 dari pengisian angket oleh 6guru. Diperoleh presentase kelayakanassessment Of Inovation Learning Berbasis Revolusi Industri 4.0sebesar 74.44\%. Berdasarkan hasil tersebut maka dapat disimpulkan bahwa penggunaan assessment of Inovation Learning Berbasis Revolusi Industri 4.0 pada uji coba terbatas memenuhi kriteria layak, karena presentase positif responden lebih dari $70 \%$.

Guru merupakan profesi tertua di dunia seumur hidup dengan keberadaan manusia. Apabila melihat kehidupan masyarakat yang semakin terdiferensial dan ketika semua orang mempunyai banyak pilihan sebagai ladang kehidupannya, maka citra profesi guru kian merosot di dalam kehidupan sosial. Apalagi masyarakat semakin lama semakin terarah kepada kehidupan matrealistis, sehingga suatu profesi dinilai sesuai nilai materinya. Oleh sebab itu, tidak heran apabila profesi guru menjadi pilihan terakhir.Secara konseptual, guru sebagai tenaga profesional harus memenuhi berbagai persyaratan kompetensi untuk menjalankan tugas dan kewenangannya secara profesional, sementara kondisi realdi lapangan masih sangat memprihatinkan, baik secara kuantitas, kualitas maupun profesionalitas guru. Persoalan ini masih ditambah adanya berbagai tantangan ke depannya yang masih kompleks di era global ini.

Assessment merupakan sebuah proses penilaian yang dilakukan untuk mendapatkan suatu informasi untuk membuat keputusan-keputusan mengenai suatu kurikulum, program-program, dan kebijakan dalam pendidikan, metode atau instrumen untuk institusi resmi yang melakukan suatu aktivitas. Uno dan Koni (2012: 2) menjelaskan bahwa assessment disebut sebagai salah satu bentuk penilaian, sedangkan penilaian merupakan salah satu komponen dalam suatu evaluasi. Secara umum, assessment dapat diartikan sebagai suatu proses untuk mendapatkan infomasi dalam bentuk apapun yang dapat digunakan sebagai dasar pengambilan keputusan mengenai siswa, baik yang menyangkut kurikulum, program pembelajaran, iklim sekolah, maupun kebijakan-kebijakan sekolah (Uno dan Koni, 2012: 2).

Assessment dalam pembelajaran adalah suatu proses atau upaya untuk memperoleh sejumlah informasi mengenai perkembangan siswa selama mengikuti kegiatan pembelajaran sebagai bahan dalam pengambilan keputusan oleh guru ataupun pihak dari sekolah untuk mengetahui dan memperbaiki proses maupun hasil belajar siswa. Dalam konteks pendidikan, pelaksanaan assessment di sekolah merupakan bagian dari proses pembelajaran yakni refleksi pemahaman terhadap perkembangan atau kemajuan siswa secara individual. Pelaksanaan assessment di sekolah-sekolah mampu meliputi kegiatan mengamati, mengumpulkan, memberi skor/penilaian, mendeskripsikan dan menginterpretasi informasi mengenai proses pembelajaran siswa.

Zainal (dalam Afifah, 2013: 1) mengungkapkan bahwa "ada kesenjangan yang besar antara assessment yang dilakukan oleh guru di dalam kelas dengan assessment yang dilakukan secara nasional atau dalam suatu daerah tertentu". Dari pendapat ahli tersebut dapat disimpulkan bahwa adanya perbedaan yang besar antara assessment yang dilakukan oleh guru untuk pembelajaran dengan assessment yang dilakukan secara nasional dalam sebuah institusi atau lembaga. Analisis kelayakan assessment Of Inovation Learning Berbasis Revolusi Industri 4.0.diperoleh dari hasil pengisian angket sebagai respon guru setelah menggunakan assessment of Inovation Learning Berbasis Revolusi Industri 4.0. Berikut disajikan hasil pengisian angket pada uji coba terbatas. Berdasarkan hasil perhitungan tabel 
pengisian angket uji coba terbatas diperoleh jumlah skor total 1072 dari pengisian angket oleh 30 guru. Diperoleh presentase kelayakanassessment of Inovation Learning Berbasis Revolusi Industri 4.0sebesar 74.44\%. Berdasarkan hasil tersebut maka dapat disimpulkan bahwa penggunaan assessment of Inovation Learning Berbasis Revolusi Industri 4.0pada uji coba terbatas memenuhi kriteria kelayakan, karena presentase positif responden lebih dari 70\%.

\section{Simpulan dan saran}

Berdasarkan pembahasan di tentang tahapan yang dilakukan untuk menghasilkan pengembangan Assessment Of Inovation Learning Berbasis Revolusi Industri 4.0. pada Guru Sekolah Dasar sebagai berikut: a) tahap pendefinisian (define), b) tahap perencanaan (design), c) tahap pengembangan (develop), d) tahap penyebaran (disseminate) . Assessment Of Inovation Learning Berbasis Revolusi Industri 4.0. pada Guru Sekolah Dasar telah memenuhi riteria 75.55\%dinyatakandalamkriteria layak dari validator ahli bahasa, 72.63\%dinyatakandalamkriteria layak dari validator ahli materi, $70.04 \%$ dinyatakandalamkriteria layak dari validator ahli desain, $68.57 \%$ dinyatakandalamkriteria layak dari validator guru.

Berdasarkan hasil penelitian, pembahasan, dan kesimpulan dapat dikemukakan beberapa saran sebagai berikut : a) Pengembangan Assessment Of Inovation Learning Berbasis Revolusi Industri 4.0 dapatdikembangkan oleh guru secara berkelanjutan untuk peningkatan kinerja. b) Bagi pembaca, dapat melakukan pengembangan yang lebih modern lagi dalambentuksoftwareagarmedia dapatmengikuti perkembangan zaman.

\section{Daftar Rujukan}

Aprilinda, Mutiara. 2019. Perkembangan Guru Profesional di Era Revolusi Industri 4.0. https//jurnal.univpgri-palembang.ac.id

Arikunto, Suharsimi. 2010. Prosedur Penelitian (Suatu Pendekatan Praktik). Yogyakarta: Rineka Cipta

Black, P., \& Wiliam, D. (1998). Assessment and classroom learning. Assessment in Education: principles, policy \& practice, 5(1), 7-74.

Daryanto \& Rahardjo, Mulyo. 2012. Model Pembelajaran Inovatif. Yogyakarta: Penerbit Gava Media

Dewi, C. (2019). Pengembangan Komik Digital Pelestarian Lingkungan Berbasis Nilai Karakter Religi Untuk Pembelajaran Tematik Pada Siswa Sekolah Dasar. Muaddib: Studi Kependidikan dan Keislaman, 1(2), 100-109.

Gibbs, G., \& Simpson, C. (2005). Conditions under which assessment supports students' learning. Learning and teaching in higher education, (1), 3-31.

Haapio, A., \& Viitaniemi, P. (2008). A critical review of building environmental assessment tools. Environmental impact assessment review, 28(7), 469-482.

Hariyani, Yulli. 2012. Pengembangan Instrument Assessment Pembelajaran Membaca Puisi Siswa SMP/MTs. jurnal-online.um.ac.id

Jaenudin, Riswan. 2009. Inovasi Model Penilaian Berbasis Portofolio dalam Pembelajaran. eprints.unsri.ac.id

Mulyatiningsih, Endang. 2013. Pengembangan Model Pembelajaran . staffnew.uny.ac.id

Nurvalah, Eva. 2016. Implementasi Authentic Assessment Dalam Pembelajaran Bahasa Arab di MTS Negeri BangBayang Kecamatan Bantarkawung Kabupaten Brebes. repository. iainpurwokerto.ac.id

Nur'afifah. 2013. Penerapan Assessment Kinerja untuk Menumbuhkan Keterampilan Menganalisis Siswa pada Pembelajaran Sejarah. repository.upi.edu

Oktharia, Ekha. 2017. Pengembangan Instrument Assessment Pengetahuan Berbasis Problem Solving pada Materi Larutan Elektrolit dan Non Elektrolit. digilib.unila.ac.id

Prasasti, P. A. T., \& Listiani, I. (2018). SETS-based guided experiment book: Empowering science process skills of elementary school students. JPBI (Jurnal Pendidikan Biologi Indonesia), 4(3), 257-262.

Riduwan. 2012. Pengantar Statistika Sosial. Bandung: Alfabeta 
Schuwirth, L. W., \& Van der Vleuten, C. P. (2011). Programmatic assessment: from assessment of learning to assessment for learning. Medical teacher, 33(6), 478-485.

Simonsson, M., Johnson, P., Ekstedt, M., \& Flores, W. R. (2011). IT governance decision support using the IT organization modeling and assesment tool. International Journal of Innovation and Technology Management, 8(02), 167-189.

Sobarningsih, Nunung. 2018. Pengenalan Assessment For Learning (AFL) Bagi Guru. ejurnal.ikippgribojonegoro.ac.id

Sugiyono. 2011. Metode Penelitian Pendidikan Kuantitatif Kualitatif dan R\&D. Bandung: Alfabeta

Uno, Hamzah B \& Koni, Satria. 2012. Assessment Pembelajaran. Jakarta: Bumi Aksara

Wiliam, D. (2011). What is assessment for learning?. Studies in educational evaluation, 37(1), 3-14. 